Revista de BIOLOGía TROPICAL

\title{
A multi-scale analysis of moisture supply associated with precipitation on Isla del Coco, Costa Rica
}

\author{
Ana María Durán-Quesada ${ }^{1,2 *}$ \& Eric Alfaro ${ }^{1,2,3}$ \\ 1. School of Physics, University of Costa Rica, 11501-2060 San José, Costa Rica; ana.duranquesada@ucr.ac.cr, \\ erick.alfaro@ucr.ac.cr \\ 2. Center for Geophysical Research (CIGEFI), University of Costa Rica, 11501-2060 San José, Costa Rica. \\ 3. Marine Sciences and Limnology Research Center (CIMAR), University of Costa Rica, 11501-2060 San José, \\ Costa Rica.
}

Received 04-V-2015. Corrected 19-IX-2015. Accepted 05-X-2015.

\begin{abstract}
Wrapped by the Pacific waters and the mist of shipwrecks and pirates stories, one of the rainiest Eastern Pacific islands protects a biodiversity treasure: Isla del Coco. This study presents the analysis of moisture sources linked with contributions to precipitation in the area. The diurnal cycle of precipitation on the island was reviewed from GPS station data previously evaluated using available meteorological data from field campaigns held on the island in 2011 and 2012. Near-surface salinity patterns were also analyzed along with sea surface temperature, evaporation, Ongoing Longwave Radiation (OLR) as well as latent and sensible heat fluxes. Moisture contributions to precipitation on the island are supplied by evaporative sources, and moisture recycling is important. Regional precipitation is a continuous supply of moisture for the atmosphere whereas transport from evaporative sources is seasonally constrained. The analysis of the diurnal cycle of moisture supply suggests that contributions from available moisture linked with precipitation recycling show a slightly delayed response to deep convection in the region. The diurnal cycle of contributions to precipitation from evaporative moisture sources, based on the modeling component of the work, is consistent with the diurnal cycle of precipitation. The trajectory analysis remarks the role of the low level winds, the Intertropical Convergence Zone (ITCZ) position and the stability conditions to modulate the supply of moisture. The moisture contributions from the sources present a different sensitivity to El Niño-Southern Oscillation (ENSO). Contributions from precipitation recycling showed a large variability linked to ENSO as increasing contributions were determined to be related with El Niño during boreal summer and autumn months. The variability of the contributions from a North-east evaporative source is modulated by the response of the Caribbean Low Level Jet (CLLJ; Amador, 1998; Amador, 2008 ) to ENSO. The South-western evaporative source showed sensitivity to El Niño, as transport was found to decrease (increase) from November to March (May to July), meanwhile the response to La Niña was small. Good agreement amongst the ENSO response of the fields and the known dynamics of the region was found. Rev. Biol. Trop. 64 (Suppl. 1): S87-S103. Epub 2016 Febrary 01.
\end{abstract}

Key words: Isla del Coco, evaporation, moisture transport, precipitation, salinity, temperature, ENSO, Eastern Tropical Pacific.

Wrapped by the Pacific waters and the mist of shipwrecks and pirates stories, one of the rainiest Eastern Pacific islands protects a biodiversity treasure (Cortés, 2008; 2012). Isla del Coco, located in Costa Rica, with a terrestrial extension of $24 \mathrm{~km}^{2}$, is located at $5^{\circ} 32^{\prime} \mathrm{N}$ $-87^{\circ} 04^{\prime} \mathrm{W}$, with its highest peak at $575.5 \mathrm{~m}$.a.s. 1 (Montoya, 2007). First known maps of the island are dated back to the $16^{\text {th }}$ century, the records of exploration visits date back to the $17^{\text {th }}$ century and research documents are dated to have started in the $19^{\text {th }}$ century (Cortés, 2008). Descriptions of organisms found on the island and surrounding waters, account for invaluable inventories of vegetation as well as marine, terrestrial and aerial animals since the late $19^{\text {th }}$ century. The island was declared UNESCO World Heritage site in 1997 and 
since 1998, it is a wetland of international importance under the RAMSAR Convention. As Isla del Coco is the only Eastern Tropical Pacific (ETP) island featured by a tropical rainforest, understanding the interactions that drive the islands precipitation is fundamental to improve our knowledge on the islands characteristics and dynamics. Furthermore, such information is key for the preservation of the island and its biodiversity on land, in the water and air. Early descriptions on the climate of the island were provided in the late $19^{\text {th }}$ century by Pittier (1898) and pioneer quantitative information was later given by Protti (1964). Modern studies based on meteorological records (Alfaro, 2008) show that weather and climate of Isla del Coco feature intense precipitation, which ranges between 5000 and $7000 \mathrm{~mm}$ per year. Currents systems, air circulation, the presence of the Inter Tropical Convergence Zone (ITCZ) among other factors, point to the island as a remarkable location to study climate phenomena such as El Niño-Southern Oscillation (ENSO) and climate change (e.g. QuirósBadilla, \& Alfaro, 2009; Maldonado, \& Alfaro, 2012). Unfortunately, long term meteorological records do not exist, data is scarce and its quality is not always ensured. Available records include data form a rain gauge operated by the National Meteorological Institute since 1979 (Fernández, 1984). However, the data record contains numerous gaps as the operation of the station was not continuous in time (QuirósBadilla, \& Alfaro, 2009).

This work combines in situ observations, reanalysis products and Lagrangian modeling to explore the relationship between observed precipitation and moisture transport at a regional scale, ranging from the diurnal cycle to interannual variability. Data from a GPS COCONet met station is used after verification of its accuracy for precipitation measurements, in absence of continuous data records in the most recent years. The study aims to determine whether the dominant wind flow plays a role on the diurnal cycle of precipitation as reported by Alfaro (2008) and how sea surface conditions response to ENSO may drive precipitation changes on the island. The links amongst moisture transport, sea surface temperature (SST), evaporation and salinity are then analyzed at different time scales.

\section{MATERIALS AND METHODS}

Precipitation includes data from the Costa Rican National Meteorological Institute (IMN in Spanish) weather station coded as 200002 . This station is located in Chatham Bay $\left(5^{\circ} 32^{\prime} 51^{\prime \prime}\right.$ $\mathrm{N}-87^{\circ} 02^{\prime} 42^{\prime}$ 'W, 151 m.a.s.1). Hourly data for the period from June 2011 to June 2012 was used. Hourly data was computed from 1 and 5 min records of a COCONet GPS automatic weather station (Protti, González, Freymuller, \& Doelger, 2012) for the June 2011 to December 2012 period. The station COCONet GPS station is coded as CocosIsl_CRI2011 and is located in Wafer Bay $\left(5^{\circ} 32^{\prime} 40^{\prime \prime} \mathrm{N}-87^{\circ} 03^{\prime} 20^{\prime}\right.$ ' $\mathrm{W}, 11$ m.a.s.l). The GPS station is equipped with Vaisala WTX510/520 meteorological package that records rain and hail precipitation by impact. The performance of the GPS station measurements is evaluated using observations from expeditions during July 2-8, 2011 and March 15-21, 2012 recorded by Davis weather stations at Wafer Bay (Cortés et al., 2011; Cortés et al., 2012). A map of the island location relative to Costa Rica is provided in Figure 1, in which the location of the observation sites is shown. The map also depicts colored topography contours so that elevation differences can be also noticed for further reference on the characteristics of the island and the location of observation sites.

Sea Surface temperature from the OISST (NOAA Optimum Interpolation Sea Surface Temperature Analysis) product (Reynolds et al., 2007) was retrieved for the period 1980-2012. The OISST product is generated using an optimum interpolation of Pathfinder AVHRR (Advanced Very High Resolution Radiometer) data. The OISST dataset has a $0.25^{\circ}$ grid resolution and coverage is global. Salinity at $5 \mathrm{~m}$ depth from the Simple Ocean Data Assimilation (SODA) dataset (Carton, $\&$ Giese, 2008) for the 1980-2012 period was 


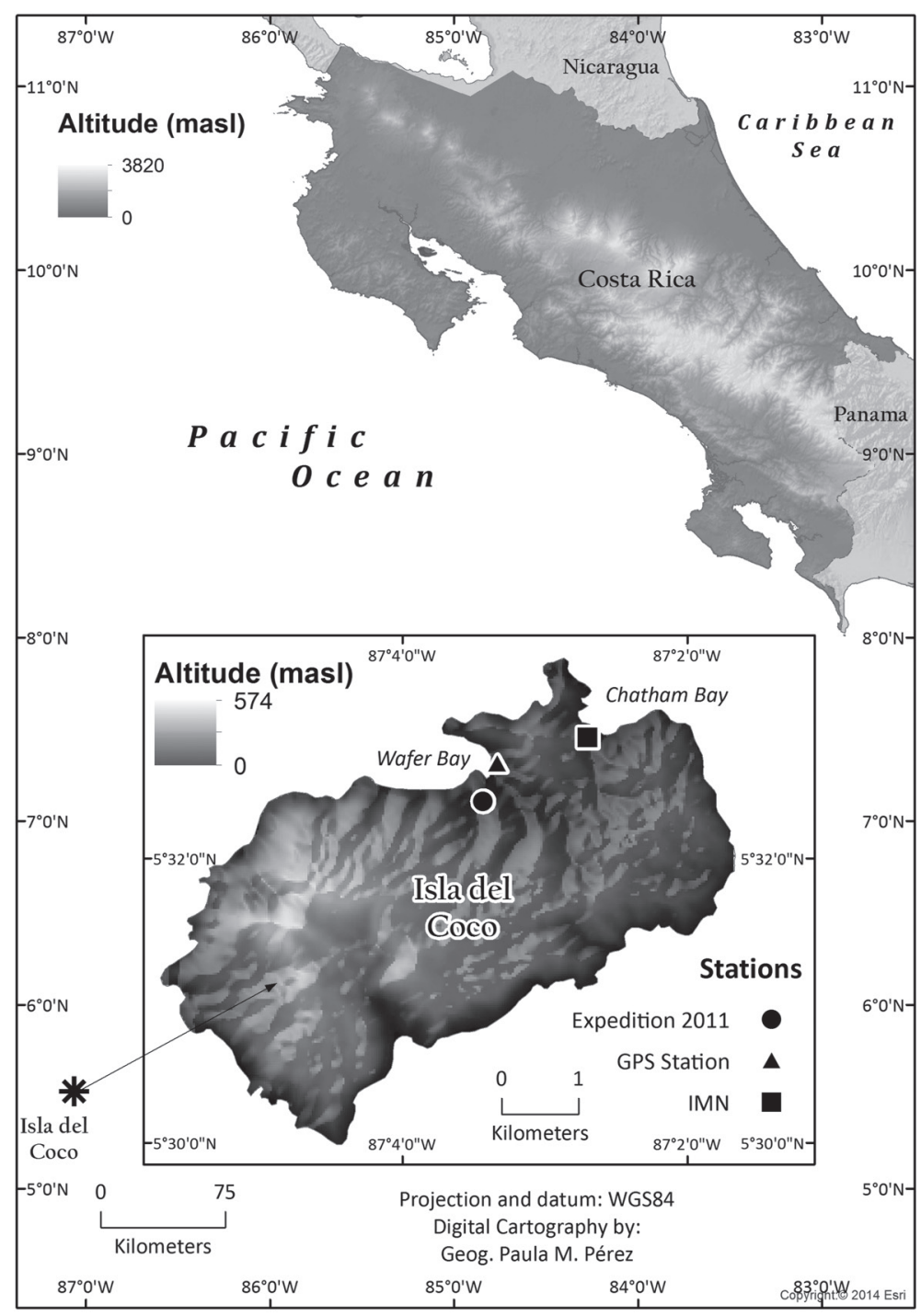

Fig. 1. Location of Isla del Coco is shown with a zoom of the island in which the location of the GPS and IMN stations as well as the location were the Davis automatic weather station was deployed at Wafer Bay during the expeditions. Shaded contours show details on the topography of the island.

retrieved, average resolution of this dataset is $0.5^{\circ} \times 0.5^{\circ}$. Input information to generate the dataset includes available hydrographic profile data, moored temperature, salinity time series, surface temperature as well as salinity observations of various types, ocean station data and infrared satellite data. Monthly evaporation, sensible heat and latent heat fluxes data in a regular $1^{\circ}$ grid of horizontal resolution from the Objectively Analyzed Air-sea Fluxes (OAFlux) Project (Yu, Jin, \& Weller, 2008) was used. OAFlux data are constructed using blending of satellite retrievals (e.g. SSMI, AMSR-E and QuikSCAT) and NWP reanalyses (ERA40, NCEP1 and NCEP2). Outgoing Longwave Radiation (OLR) monthly mean data from the 
AVHRR instrument, available on a $2.5^{\circ} \times 2.5^{\circ}$ grid from the Climate Diagnostic Center site were used (Chelliah, \& Arkin, 1992).

Using a numerical water vapor tracer (WVT) method, the source-receptor relationship was analyzed to determine the sources of moisture for Isla del Coco and its vicinity precipitation. The method tracks the air masses that circulated over the island up to ten days back in time using the information of backward trajectories. The Lagrangian backward trajectories were generated for a global domain using the Lagrangian particle dispersion model FLEXPART (Stohl, Forster, Frank, Seibert, \& Wotawa, 2005) and ERA-Interim data (Dee et al., 2011). Reanalysis data every $6 \mathrm{hr}(00,06,12$ and 18) and analysed for the intermediate $3 \mathrm{hr}$ time steps $(03,09,15$ and 21) were used as FLEXPART input. A Lagrangian approximation of the Eulerian budget equation was used to estimate the evaporation and precipitation difference integrated over an atmospheric column to identify the sources of moisture (see details in Stohl, \& James, 2004). Once the moisture sources were identified, the transport of moisture was estimated and time series were computed from hourly to monthly time scales. A clustering algorithm based on Dorling, Davies \& Pierce (1992) was applied to reduce the number of trajectories and show explicitly the mean structure of the moist flux that contributes to precipitation on the island. Composites of SST, surface fluxes, evaporation and salinity were computed for the five strongest ENSO events between 1980 and
2012 based on the Multivariate ENSO Index (MEI) and Nino 3.4 indices. Table 1 shows the detailed information on the events selected for the compositing.

\section{RESULTS AND DISCUSSION}

\section{GPS automatic station measurements performance test}

The deployment of the COCONet met station at Wafer Bay is seen as a good opportunity to obtain complementary information to that provided by the IMN station. Considering the high frequency of the observations, data are useful for the analysis of rain showers duration and intensity as provided by Alfaro \& Hidalgo (2016). However, the WXT520 is indicated to be more suitable for short-term deployments as the instrument is not intended for research performance purposes. As the objective of this work is to use the GPS met station precipitation information for a longer time span (18 months), an evaluation on the performance of the GPS met station is required. A comparison between the GPS met station data and data from weather stations deployed during the expeditions was performed.

The overall results suggest that the information provided by the sensors of the GPS met station can be considered as reasonably accurate for the temperature, precipitation and wind speed variables. A good agreement between the GPS met and Davis automatic stations measurements was found during the

TABLE 1

Years used to compute the warm and cold ENSO monthly composites

\begin{tabular}{lcccccccccccc} 
& Jan & Feb & Mar & Apr & May & Jun & Jul & Aug & Sep & Oct & Nov & Dec \\
El Niño & 1983, & 1983, & 1983, & 1983, & 1983, & 1987, & 1987, & 1987, & 1982, & 1982, & 1982, & 1982, \\
& 1987, & 1987, & 1987, & 1987, & 1987, & 1991, & 1991, & 1991, & 1987, & 1987, & 1987, & 1986, \\
& 1992, & 1992, & 1992, & 1992, & 1992, & 1992, & 1997, & 1997, & 1997, & 1997, & 1997, & 1997, \\
& 1998, & 1998, & 1998, & 1993, & 1993, & 1997, & 2002, & 2002, & 2002, & 2002, & 2002, & 2002, \\
\multirow{4}{*}{ La Niña } & 2010 & 2010 & 2010 & 1998 & 1997 & 2002 & 2009 & 2004 & 2012 & 2009 & 2009 & 2009 \\
& 1989, & 1989, & 1989, & 1985, & 1988, & 1988, & 1985, & 1988, & 1988, & 1983, & 1983, & 1984, \\
& 1999, & 1999, & 1999, & 1989, & 1989, & 1985, & 1988, & 1998, & 1998, & 1988, & 1988, & 1988, \\
& 2000, & 2000, & 2000, & 1999, & 1985, & 1999, & 1998, & 1999, & 1999, & 1998, & 1998, & 1998, \\
& 2008, & 2008, & 2008, & 2000, & 1999, & 2000, & 1999, & 2007, & 2007, & 1999, & 1999, & 1999, \\
& 2011 & 2011 & 2011 & 2001 & 2000 & 2001 & 2010 & 2010 & 2010 & 2010 & 2010 & 2010 \\
\hline
\end{tabular}




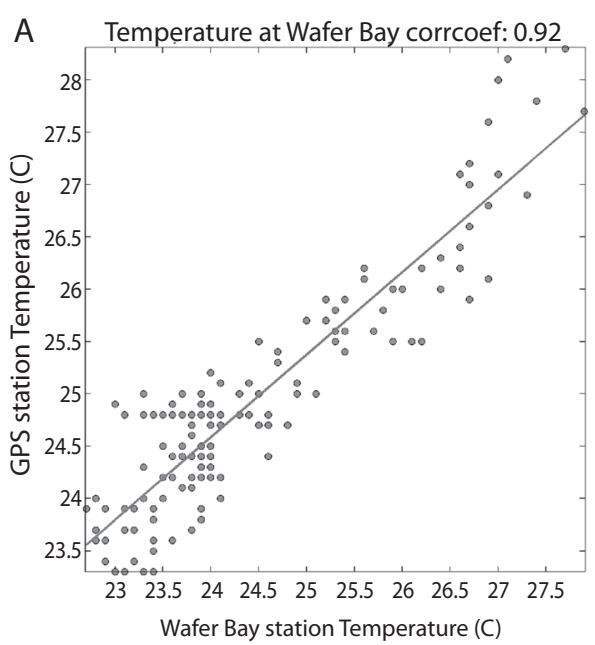

B Relative Humidity at Wafer Bay corrcoef: 0.64
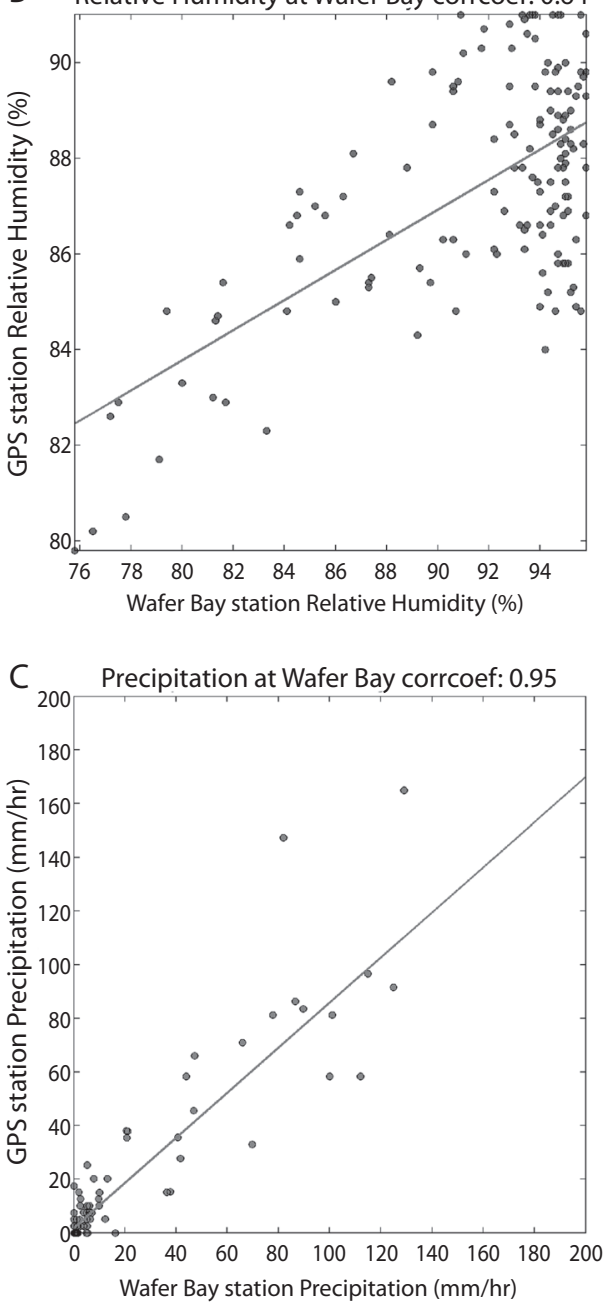

expeditions in 2011 and 2012. Figure 2 shows the correspondent scatter plots for temperature, relative humidity and precipitation. Temperature observations (Fig. 2a) present a large correlation and show that during the expeditions, temperature ranged between $23^{\circ} \mathrm{C}$ and up to $30^{\circ} \mathrm{C}$ so that diurnal thermal amplitude in the island is considered to be large. Despite the comparison of relative humidity (Fig. 2b) shows more widespread results, observed differences may respond to the emplacement of the stations, regardless being located in the same bay. As observed in Figure 1, the GPS met station is located more inland compared to the site of the expeditions observations, hence the observations from the expedition have a stronger influence of marine conditions. It is also important to mention that the expedition observations appear to be capped for values larger than $93 \%$ and this may also influence the results. A more appropriate comparison would be the use of specific humidity, however, there were not enough information available to estimate the specific humidity and use this variable instead of relative humidity. A longer time period of observations is still needed to determine whether the emplacement of the stations is enough to explain this result or if there might be sensitivity issues with the humidity sensors of the GPS met station. Precipitation measurements between the two stations are coherent (Fig. 2c), notice that the range of precipitation corresponds to the 2011 expedition and that observations were used at an hourly rate. Information from the GPS met station shows reasonable skills to reproduce the diurnal cycle, mainly of temperature and precipitation. Moreover, based on historical precipitation data, the GPS met station performance is also accurate to capture intense rainfall events (not shown).

Fig. 2. Comparison of observations of the GPS station sensors and the expeditions deployments, both at Wafer Bay during July 2-8, 2011 and March 15-21, 2012. GPS station observations were averaged (or accumulated) over hourly periods to match the resolution of the expeditions observations for (a) Temperature; (b) Relative Humidity and (c) Precipitation. 
The comparison for wind is not presented as the location of the stations in the bay is such that wind direction measurements are not comparable. However, it is worth mentioning that wind speed measurements were consistent in terms of magnitude. To be more conclusive in terms of the data quality from the GPS station, control for a longer time span and the use of a higher quality humidity sensor is required for more detailed ground tests.

\section{The annual cycle of moisture transport linked with precipitation on Isla del Coco}

Alfaro (2008) suggested that the diurnal cycle of precipitation on Isla del Coco was strongly forced by the wind field. The overall effect of wind on the islands precipitation can be understood in terms of local and remote components. Such components include air-sea breeze, topographic effects and radiative forcing of precipitation by local differential heating. For precipitation, large scale forcing on the winds is an important constraint, as its role to modulate moisture transport and availability is well known in the region (Durán-Quesada, Gimeno, Amador, \& Nieto, 2010; Durán-Quesada, 2012). To determine the importance of the wind driven moisture transport linked to precipitation on the island, the moisture sources for local precipitation were identified. The spatial scale of the transport and the locations where moisture uptake is larger were determined from Lagrangian trajectories analysis.

Air masses that supply moisture for precipitation in the vicinity of Isla del Coco have a regional origin as shown in Figure 3. The results suggest that moisture contributions to
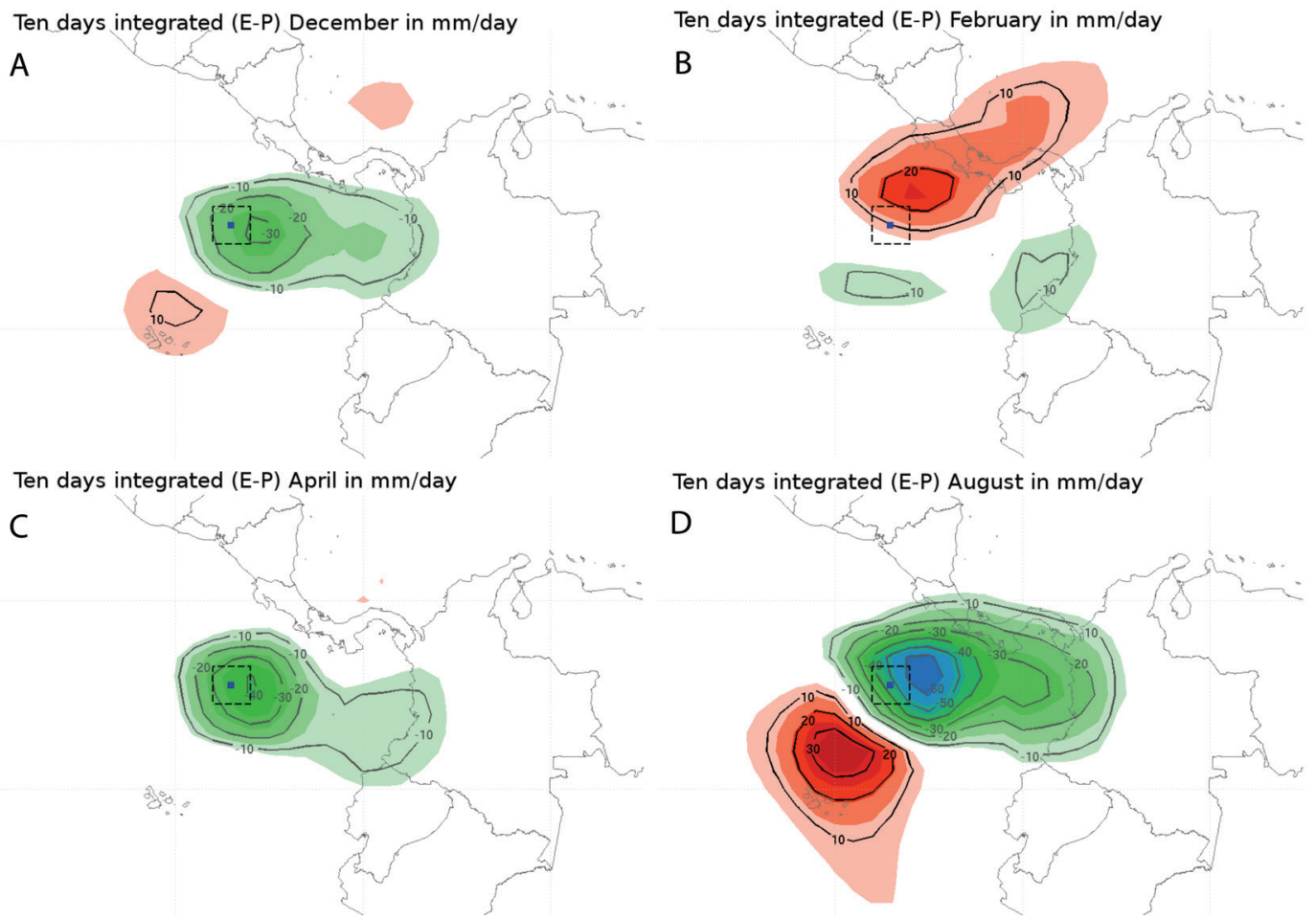

Fig. 3. Climatology of ten days integrated (E-P) as computed from the Lagrangian backward trajectories for air masses precipitating inside the dotted line box for (a) December; (b) February; (c) April and (d) August. Positive values show the evaporative sources of moisture, hence moisture uptake locations. Negative values show regions where precipitation recycling might be a source of moisture availability for precipitation on Isla del Coco. The location of Isla del Coco is shown by the blue dot and the area for analysis is the black lines square. Ten days was used as it was the average time residence of water vapor. 
the island come from evaporation over the ETP and the westernmost edge of the Caribbean Sea (red shading in Fig. 3). Green and blue shading in Figure 3 show the regions in which precipitation exceeds evaporation, these areas are observed over the easternmost Tropical Pacific. Even when they do not account as moisture sources themselves, they play an important role in increasing the moist content of the atmosphere. If this precipitation re-evaporates, is transpired or recycled (depending on the underlying surface), the moisture supply for precipitation increases and it can be considered as a net moisture contribution to precipitation. The moisture sources present a well defined annual cycle, between November and January, small contributions from the inner Caribbean and South-West of the island were detected. Precipitation largely exceeds evaporation in the easternmost tropical Pacific due to the presence of the ITCZ (Fig. 3a). Most of the atmospheric moisture available in the region is linked to large scale rain producing systems. As shown by the averaged trajectories in Figure $4 a$ the moisture uptake is limited to the island vicinity. The structure of the moisture transport depicts an enhancement of the easterly low level flow. As the easterly flow is intensified by the secondary peak of the CLLJ, evaporation in the inner Caribbean and to the North-East of the island (Fig. 3b) becomes the main moisture supplier during February. During boreal winter months, the CLLJ is the main moisture conveyor for Isla del Coco. The dynamics of this evaporative moisture source is very complex as it is related with the large scale circulation forcing and its interaction with the region, exhibiting also a strong air-sea coupling. Note that the (E-P) ${ }^{-10}$ maximum shown in Figure $3 b$ is located over a region of warmer SST and of a deeper $20^{\circ} \mathrm{C}$ isotherm (see Fig. $4 \mathrm{~b}$ from Xie, $\mathrm{Xu}$, Kessler, \& Nonaka, 2005). It is important to remark that even when the air masses might have their origin in the Caribbean and the major moisture uptake takes place in the ETPac, the contributions from the Caribbean are not negligible. As the CLLJ decreases in intensity, the Caribbean influence retreats and the evaporative source of moisture once located to the east of the island vanishes. Precipitation over the ETPac is now lead by the activity of the ITCZ and the development of convection over the Panama Bight region. The intensification of precipitation increases moisture availability in the vicinity of Isla del Coco (Fig. $3 \mathrm{c}$ ). Note that during these months, the ITCZ meridional migration (following the summer hemisphere) is northward, therefore, precipitation is enhanced over the ETP and moisture supply from evaporative sources is not detected. Few months later, the CLLJ reaches its summer maximum but different from February, the regional conditions do not favor moisture transport. Enhanced precipitation may supply moisture to the island surrounding atmosphere during the following months with contribution showing a peak between June and September (see green and blue shaded area in Fig. 3d). The results show that after May, an evaporative moisture source starts its development southwest of the island. This evaporative source of moisture becomes strongly active between June and September (see red shaded area in Fig. 3d) until it starts to decrease after September. The presence of this strong evaporative source responds to the combination of increasing evaporation in the ETP and the strengthening of the southwesterly low level flow. SST becomes warmer (sensible heat increases), evaporation is enhanced and the release of latent heat increases. The latter increases the moisture content of the atmosphere. Low level winds transport the moist air to the vicinity of the island where it can contribute to precipitation. As noticed from Figure 4c, the south flow transport the air masses towards Isla del Coco, intense uptake occurs South-west of the island and moisture supply from this source is intensified. Note that during August, the moisture content in the ETPac is very large as convective processes and evaporation are intense. Figure 4 highlights the role of regional low level winds for the transport of moisture, for reference, the average level of the trajectories shown is below $750 \mathrm{hPa}$. To summarize, moisture transport from the two evaporative sources of moisture 


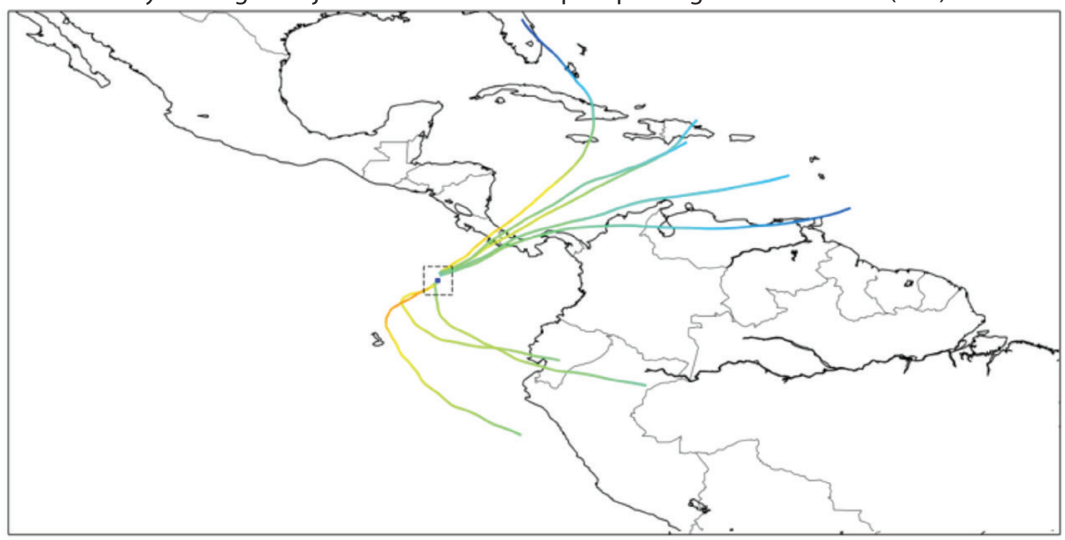

B 6 days averaged trajectories of air masses precipitating on Isla del Coco (Feb)

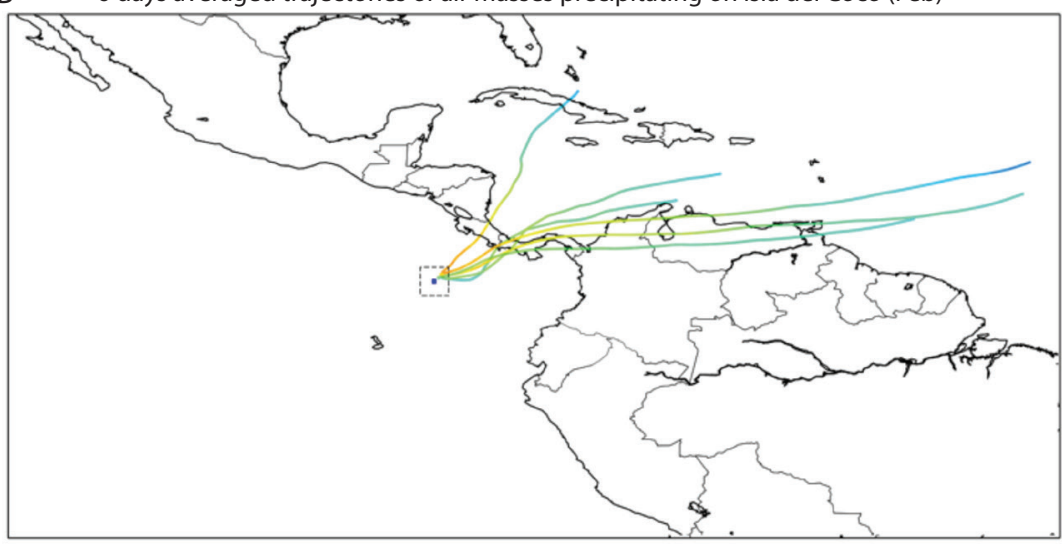

C 6 days averaged trajectories of air masses precipitating on Isla del Coco (Aug)

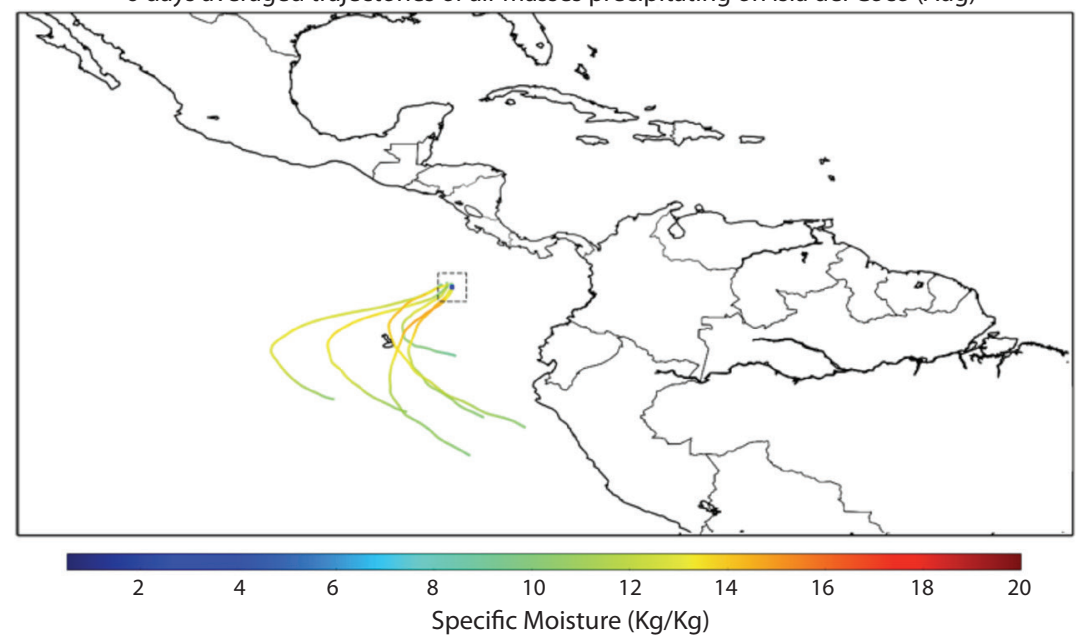

Fig. 4. Six days climatological clusters (1980-2012) Lagrangian backward trajectories for air masses precipitating on Isla del Coco and surrounding waters (the island is shown by the blue dot and the area for trajectories arrival is shown by the black square). Colors show the specific humidity in $\mathrm{Kg} / \mathrm{Kg}$ as obtained from the modeling results. The figures clearly show that the maximum moisture uptake occurs in the waters surrounding the island. 
was estimated and monthly averaged. Black solid lines in Figure 5 shows the annual cycle of moisture contributions. Moisture transport due to easterly winds (Fig. 5a) peaks during boreal winter, the decrease in moisture contributions from this source is abrupt and a slight increase is observed during the summer months when the easterly flow intensifies again, in good agreement with the annual cycle of the CLLJ. Meanwhile, moisture transport from the South-west evaporative source identified increases from April to September (Fig. 5b). Despite this source is active for a longer period, the intensity of its contributions is smaller than easterly transport. The activity of both evaporative sources is strongly seasonally constrained. The annual cycles provided in Figure 5 show that Isla del Coco have a continuous moisture supply all year round. The ITCZ and convective systems development account for precipitation on the island, but it is the moisture transport which sustains the moisture availability required for rain producing systems locally and hence help to provide the conditions on the island for the existence of a rain forest.

\section{Diurnal cycle of moisture supply: effect on precipitation on Isla del Coco}

The diurnal cycle of precipitation on Isla del Coco is driven by the influence of low level winds, the ITCZ position and the stability conditions near the island (Alfaro, 2008). Within this volume, Alfaro \& Hidalgo (2016) remark local differences in the diurnal cycle of precipitation at Chatham and Wafer bays based on available observations (see their Fig. 1). According to their results, unlike Wafer Bay, a peak of afternoon summer rainfall is reported at Chatham. At Wafer Bay, precipitation peaks at late morning from January to March, at the afternoon from April to May and at the early morning during June to September, while December tends to be a drier month. Here we aim to answer two questions, whether the transport of moisture has a diurnal cycle and, if so, how it modulates the diurnal cycle of precipitation.

Moisture contributions from the evaporative sources were computed at an hourly time scale, in addition, Lagrangian precipitation estimates were used to approximate the recycling of ETPac precipitation on Isla del Coco. The 1980-2012 monthly mean of the diurnal cycle of moisture contributions to Isla del Coco precipitation are shown in Figure 6. The recycling of moisture (Fig. 6a) peaks in the early morning and late afternoon between November and April. This result is coherent with the diurnal cycle of precipitation estimated from observations, encouraging the capability of
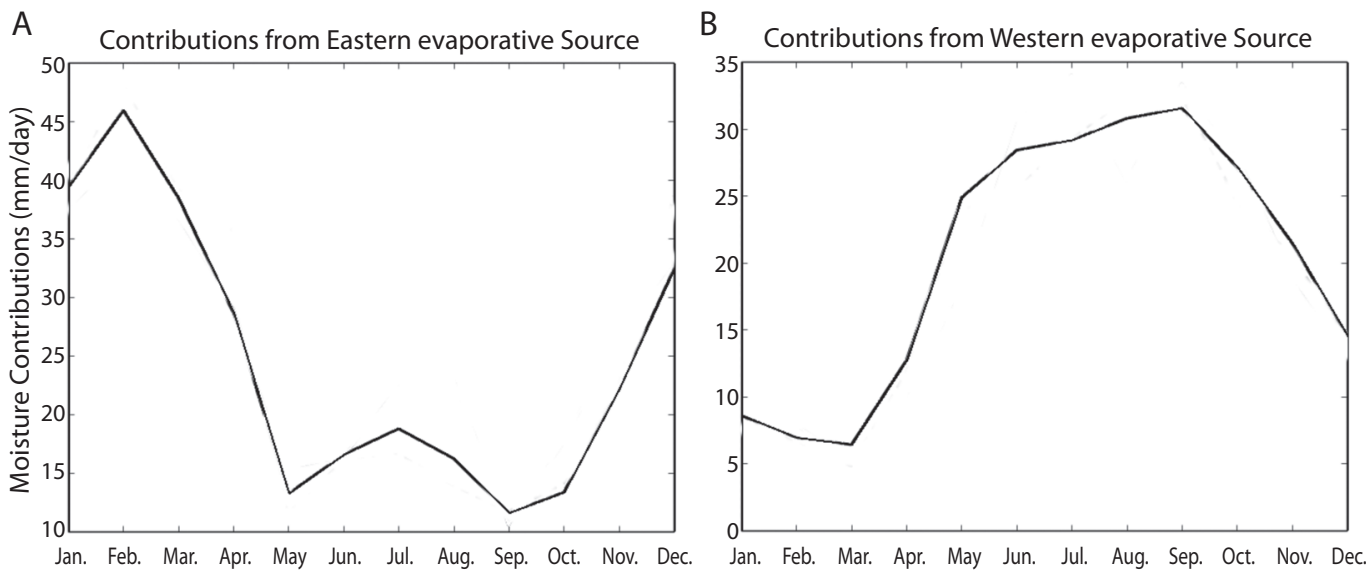

Fig. 5. Monthly composites of the moisture transport from the evaporative moisture sources to precipitation on Isla del Coco. Figures show the marked annual cycle of the moisture transport from the evaporative sources identified as suppliers for Isla del Coco precipitation. 

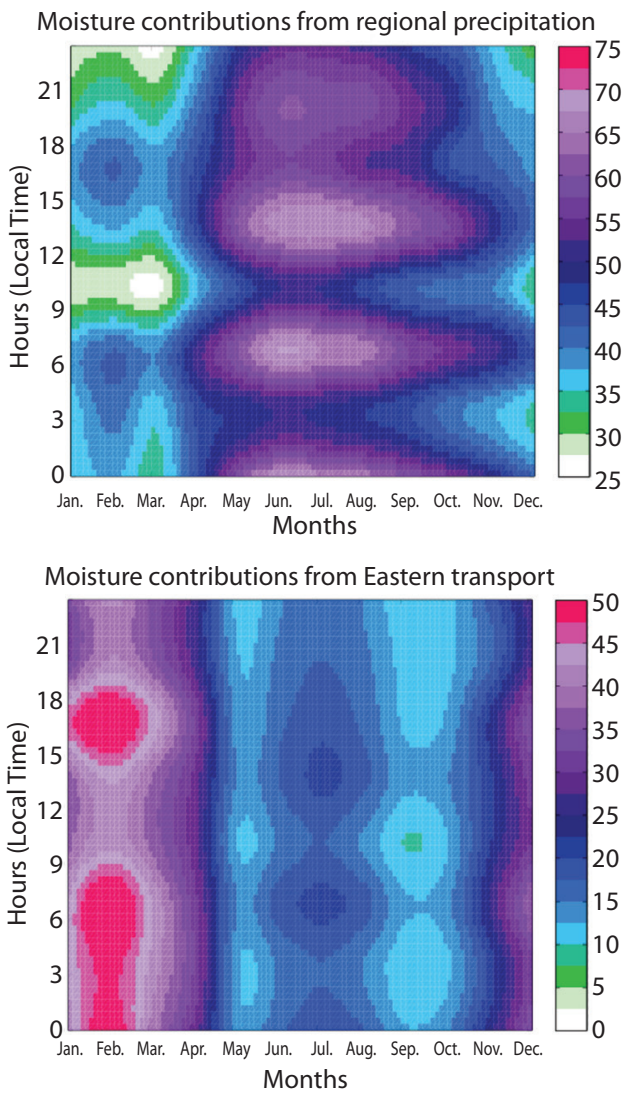

Moisture contributions from South-Western transport

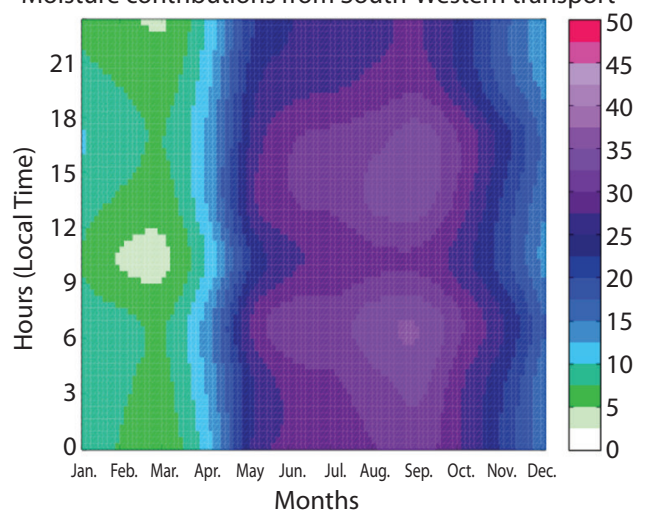

Fig. 6. Diurnal cycle of moisture transport (monthly averaged) from the sources of moisture to the vicinity of Isla del Coco (dotted line box in Fig. 2) using threehourly means of the 10 days integrated net fresh water flux computed with the Lagrangian backward trajectories, units in $\mathrm{mm} /$ day. (a) Evaporative source of moisture located to the North-East of the island; (b) Evaporative source of moisture located to the south-west of the island. the model to capture the moisture variations at such scales. For this period, moisture transport from the eastern source is enabled and as shown in Figure $6 \mathrm{~b}$, transport from this source peaks in the same window. During the peak of moisture transport from the eastern source, precipitation occurs in the late morning hours. We can infer that precipitation on the island is diurnally driven by long range moisture transport from the Easternmost Tropical Pacific and the inner Caribbean. Between June and August precipitation recycling and moisture transport from the south-western source (Fig. 6c) peak in the morning and early afternoon hours. We highlight the strong relationship between the transport of moisture and the timing of precipitation.

Moisture exports from the remote source located to the north-east of the island have a marked annual cycle that peaks during February (Fig. 6b). As previously indicated, the CLLJ is the conveyor for regional moisture transport from both evaporative sources. Cook \& Vizy (2010) demonstrated that, the meridional wind is more intense at 10:00 (local time) for the southerly flow. Intensified wind flow from the South during the late morning might be reflected in the minimum of transport observed as the island is located south of the winds veering. Transport from the southwestern source is maximum between August and November (Fig. 6c). The wind field during these months is featured by the increase of a south-westerly flow. This flow is known to be related with the development of the Chocó jet (Poveda, \& Mesa, 2000) and has being also identified as a moisture conveyor for Central America (Durán-Quesada et al., 2010; DuránQuesada, 2012). Moisture transport due to the Chocó jet is slightly larger during the morning. The diurnal cycle of the Chocó jet responds, among other mechanisms, to the development of mesoscale convective systems over the offshore Pacific coastline (Poveda, Waylen, \& Pulwarty, 2006). The forcing of the diurnal cycle of the Chocó jet, can be inferred from known results that show that convective 
systems are more likely to develop at 0600 and 1500 local time (Mapes, Warner, Xu, \& Negri, 2003). Figure 6c shows that in fact, transport from this source is larger in the same time window. The diurnal cycle of the moisture supply from the south-western source is modulated by the Chocó jet forcing due to the development of convective systems. The results obtained with the Lagrangian modelling approach used in this study are coherent with the near-land regional timing of convection in the eastern Pacific. Bain, Magnusdottir, Smyth \& Stern (2010) showed that despite an east-west shifting, convective activity in the ITCZ peaks in the early morning and afternoon. A similar timing was found by Mapes et al. (2003) for mesoscale convective systems developing over western Colombia and the Panama Bight.

\section{Moisture transport response to ENSO}

Isla del Coco is located in a region where the response of SST, OLR and surface fluxes to ENSO shift (Quiros-Badilla, \& Alfaro, 2009). This makes the island an ideal location to study the effect of ENSO on the regional distribution of precipitation. This part of the study focuses on the analysis of the regional response of SST, evaporation, OLR, salinity and surface fluxes to ENSO and associated changes in the moisture transport to the island from the evaporative sources as well as the contributions from precipitation recycling. In general terms, precipitation recycling and moisture transport show a contrasting response to ENSO phases as shown in Figure 7 by the composited annual cycles for El Niño (black solid line) and $\mathrm{La}$ Niña (gray dotted line). Precipitation recycling shows a larger response to ENSO during boreal summer as the recycling increases (decreases) for El Niño (La Niña) as shown in Figure 7a. This result is in agreement with the intensification of precipitation in the vicinity of the island during El Niño events. Contributions from the eastern evaporative source (Fig. 7b) present a strong sensitivity to the seasonal response of the wind field to ENSO. This is, an opposite

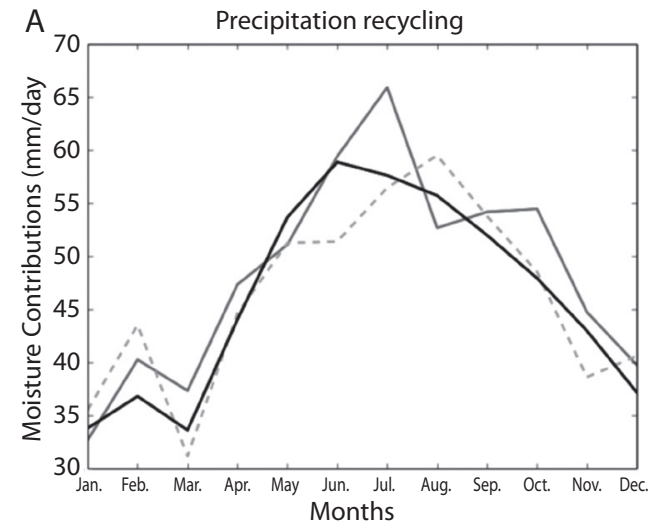

B Contributions from Eastern evaporative Source

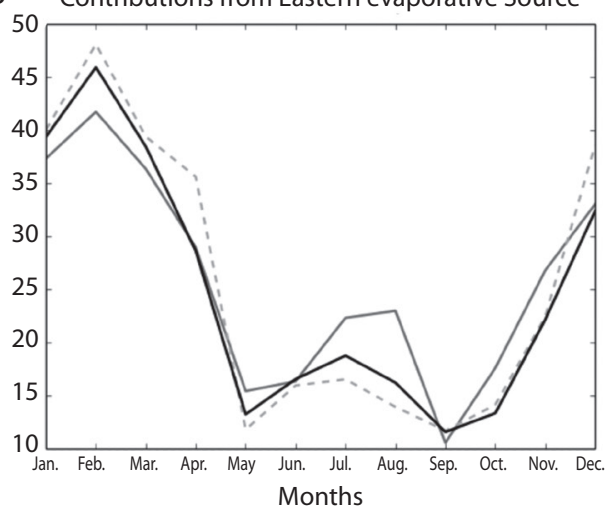

C Contributions from Western evaporative Source

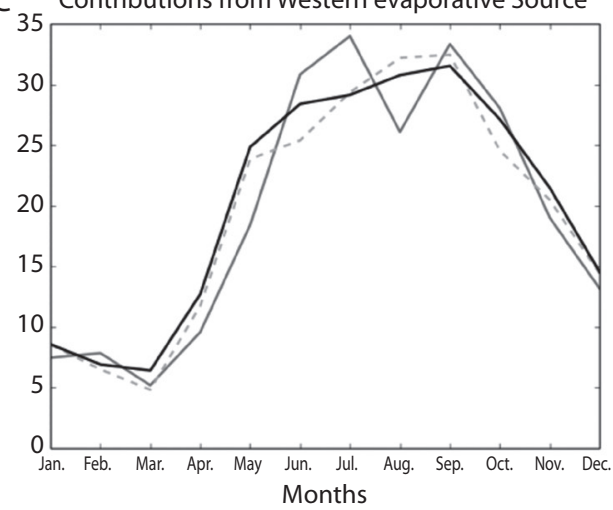

Fig. 7. Composites of the moisture supply from the moisture sources to precipitation on Isla del Coco (black solid line for the average contributions, solid grey line for contributions under El Niño and dotted grey line for contributions under La Niña). Units in $\mathrm{mm} /$ day, (a) contributions from precipitation recycling and moisture transport from (b) evaporative source of moisture located to the North-East of the island and (c) evaporative source of moisture located to the south-west of the island. 
response to the ENSO phases during winter and summer months. For February-March transport increases (decreases) for La Niña (El Niño) while for June-August transport is more intense (weaker) during El Niño (La Niña) events. The response of this source to ENSO is completely lead by the dependence on the low level wind flow. Note that the observed response of the moisture transport to ENSO forcing is actually the fingerprint of the CLLJ response to ENSO. The CLLJ is known to be stronger (weaker) in summer for El Niño (La Niña) while the opposite is observed for winter. The difference between the response of the western moisture source to ENSO phases is larger between May and September (Fig. 7c). From May to July moisture transport from this source is enhanced (decreased) for El Niño (La Niña) while after July the observed response is opposite. As the western source reaches its maximum intensity after July, the result may imply that under, El Niño conditions, the moisture weakens. Therefore, a decrease in precipitation on the island for these months is suggested as the moisture supply is reduced.

To evaluate how does observed precipitation variability relates with the modeling results for moisture supply, results from Quirós-Badilla \& Alfaro (2009) are considered to alleviate the poor long term data availability on the island. Quirós-Badilla \& Alfaro (2009) found that El Niño events are related with above normal precipitation and the opposite was determined for La Niña events, being the signal detected stronger for October. The results obtained in this work show that moisture supply is increased under El Niño conditions mostly during the summer months consistent with the enhanced precipitation for warm ENSO. However, a decrease in moisture transport from the western source as well as in moisture recycling was detected during August and a deficit in overall moisture contributions from the sources was found for August under El Niño. Monthly composited differences of TRMM precipitation during El Niño and La Niña events were computed in order to evaluate the regional scale precipitation response.
Based on TRMM data, El Niño is associated with a decrease in precipitation over the ETPac north of the equator during August. Therefore, the moisture supply decrease is consistent with observed precipitation reduction in the ETPac. This contrasting result with Quirós-Badilla \& Alfaro (2009) may reflect continuity and quality issues with the observational data used in their study as well as the dominance of local conditions on the island not reproducible by the trajectories and captured by TRMM due to horizontal resolution. During the January to early March, the transport of moisture and precipitation recycling decrease during El Niño as does daily rainfall according to TRMM composites.

SST, OLR, latent heat and sensible heat fluxes, evaporation and salinity are considered to evaluate links that may provide us with further information about ENSO forcing on moisture supply processes. Considering the strong signal detected by Quirós-Badilla \& Alfaro (2009) and the precipitation recycling peak found in this study for October, further fields are analyzed. The SST distribution (Fig. 8a) during El Niño features the associated warming in the tropical Pacific. Increased SST accelerate winds due to thermal gradients, notice the Caribbean-Pacific SST gradient despite the CLLJ is minimum for this month. Via such mechanism, winds that transport moisture from the north-eastern source can be modulated and the contributions from the source change, as shown in Figure 7c. OLR differences (Fig. 8b) show the enhancement of convection as depicted by negative OLR values during El Niño.

The air-sea coupling in the vicinity of Isla del Coco is of importance as it defines not only regional weather and climate but biological processes. The distribution of salinity, is driven, in general terms, by the difference between evaporation and precipitation as well as the freshwater discharge of rivers (for further details on salinity distribution in the ETPac please refer to Amador et al., 2016 in this volume). Isla del Coco lies under the ITCZ and nearby the Pacific coast of Colombia, where strong convective systems seed heavy rainfall in a region in which river discharge 
A

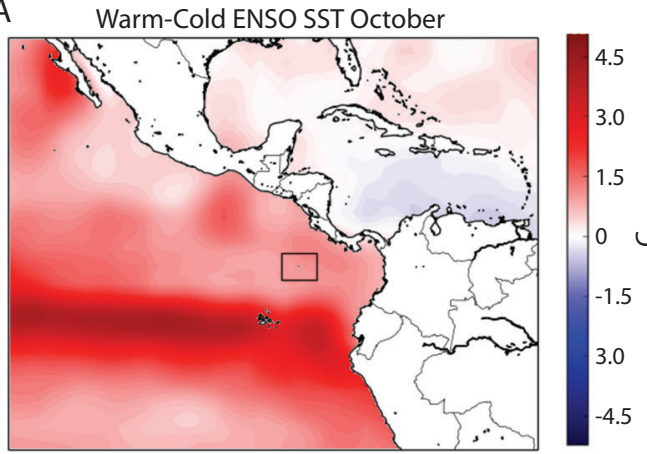

C Warm-Cold ENSO Evaporation January
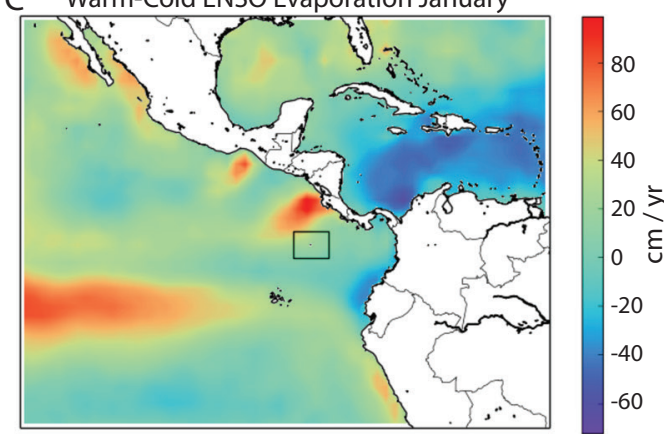

B

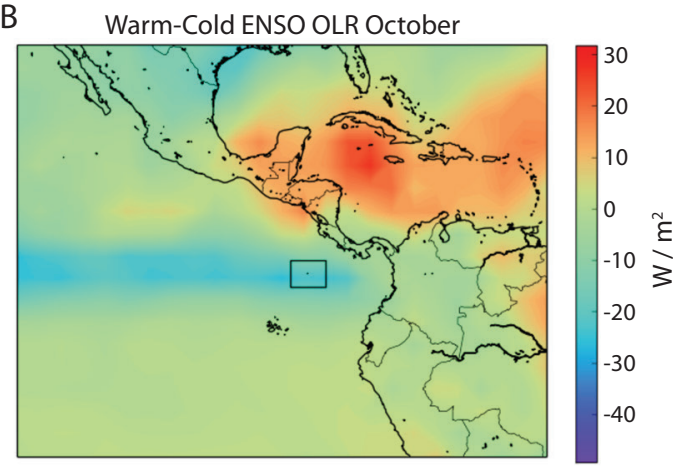

D

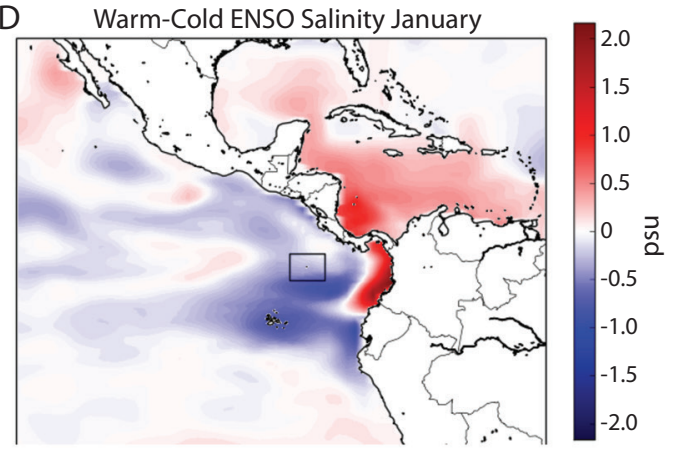

Fig. 8. Composite differences between warm and cold ENSO for (a) SST in October; (b) OLR in October; (c) Evaporation in January and (d) Salinity in January.

into the ETPac is very large. Evaporation in the region is forced by large SSTs but is also wind driven (see in Fig. 8c the evaporation maxima west of the Tehuantepec and Papagayo gaps for January). During January, under El Niño conditions, the intensification of precipitation largely exceeds evaporation. As a result, salinity decreases in the waters that surround the island as shown in Figure 8d. However, the suppression of deep convection west of Colombia and the consequent reduction of precipitation over some locations of South America, are associated with an increase in the salinity in the coastal regions of Panama and Colombia as shown in Figure 8d by the red shading. As observed from that figure, this generates a strong salinity gradient east of the island that may induce a circulation due to density differences. This salinity gradient must be studied in terms of the impacts of ENSO for productivity in the waters surrounding the island.

\section{CONCLUSIONS}

The scarcity of long-term meteorological observations on Isla del Coco can be alleviated by considering the use of a GPS met station deployed for seismic purposes. Even when instruments on the currently GPS station operating on the island are not intended for research performance purposes. Based on comparisons with an automatic meteorological station data, the quality of the information is considered as fairly good for research applications in absence of other high quality meteorological observations. It is worth mentioning that, a longer time span analysis is still required to be conclusive in terms of assuring the quality of the GPS station meteorological data, as the evaluation performed only included short periods of available observations from field campaigns on the island.

The results of the WVT method applied to study moisture transport and contributions 
to precipitation on Isla del Coco allowed us to determine the islands main moisture suppliers. Moisture sources were identified to be linked with contributions from evaporation from both Eastern Tropical Pacific and the Caribbean Sea as well as the recycling of moisture. The clustering analysis of backward trajectories reproduced the transport as dominated by regional low level winds and constrained by the seasonal migration of the ITCZ. Furthermore, deep convection related with mesoscale convective systems over the Panama Bight was found to act as a modulator of precipitation-linked moisture contributions.

The annual cycle of moisture transport was determined to be controlled by the transport of moisture and the diurnal cycle of mesoscale convective systems development. Based on the results we can conclude that precipitation on the island is seasonally forced by regional winds but diurnally driven by large scale convective processes. Observational data is needed to properly understand the diurnal wind regime on the island beyond the known local timing of land-sea breeze. As the CLLJ strengthens during the first trimester of the year, northeasterly moisture transport increases and precipitation is lead by the low level winds and local atmospheric stability. When moisture transport retreats, precipitation is controlled by large-scale convection until the south-westerly flow and evaporation enhances the transport of moisture South-west of the island.

Transport of moisture exhibits a well defined diurnal cycle, precipitation recycling peaks at early morning and afternoon, in good agreement with large scale precipitation maximum values. However, moisture availability is not necessarily linked with rain so that further research on local stability conditions suitable to enhance precipitation are needed. A relevant aspect to consider is that when the evaporative sources are active, the release of latent heat is linked to a more unstable atmosphere and this may play an important role in determining whether convection develops or not. The analyzing of the diurnal cycle of the moisture transport, it was found that transport related with the CLLJ does not seem to show a very marked diurnal cycle whereas for transport related with the Chocó jet the diurnal cycle of transport is slightly delayed with respect to the known diurnal behavior of the development of convective systems offshore the Pacific tropical South American coastline.

Moisture supply is sensitive to ENSO, in general terms contributions increase (decrease) during El Niño (La Niña) events. However, the response of the moisture supply to ENSO requires individual month analysis as the response changes. The north-east evaporative source shows a significant response to the seasonally forced ENSO response of the low level wind flow. Transport from this source is enhanced (decreased) for La Niña (El Niño) during February-March while presents the opposite behavior for June-August and October-November. The south-western evaporative source response to La Niña is very small. In contrast, for El Niño, transport is largely increased between June and July, and decreased during August.

The evaluation of ENSO sensitivity of precipitation, SST, evaporation, OLR and salinity show how increases of SST may force winds via the enhancement of the Caribbean-Pacific SST gradient. This is reflected in the modulation of the north-eastern source moisture transport. Enhanced convection linked to warm ENSO increases as seen from OLR data. The relationship of the difference between evaporation and precipitation with the spatial distribution of the sources of moisture was also analyzed considering near-surface salinity. It was found that despite evaporation being largely forced by the SST distribution, wind driven evaporation is important when the low level flow is enhanced by the topographic gaps in the Central American Isthmus. Therefore, the response of evaporation and its influence on salinity to ENSO depends on how this variability mode modulates regional low level winds. Variability of salinity distribution, showing increasing salinity under El Niño, was found related with the suppression of deep convection west of Colombia. 
Beyond the analyses presented in this work, the results could motivate further studies to asses new emerging scientific questions. To understand in detail the diurnal cycle of precipitation on Isla del Coco and its relationship with the interaction between moisture transport and the geographical features of the island, it is important to conduct specific studies in which the vegetation on the island is considered. Moreover, the problem of the diurnal cycle of moisture transport requires either higher resolution wind and humidity information or long terms in situ stations located in an arrangement in a transect of the island that includes elevation observations. To account for more information on how the ENSO mode affects the island and its ecosystems, considering the vertical variations in the distribution of salinity is fundamental. The latter as strong salinity gradients forced by ENSO may lead to vertical circulations that may have a potential for the productivity of the island and its surrounding biodiversity.

\section{ACKNOWLEDGMENTS}

The authors acknowledge the Continuously Operating Caribbean GPS Observational Network (COCONet) project funded by the National Science Foundation (NSF) and the Costa Rica National Meteorological Institute for making data available. AMDQ acknowledges John Braun for GPS observation network data and discussions. The authors thank Paula Pérez for Figure 1. Support with data retrieval, processing and assistance with construction of figures by students Daiana García, Pedro Chávez, Aaron Vega and Esteban Rodríguez respectively is acknowledged. This work was supported also by CIMAR and CIGEFI, UCR grants: 808-B0-654 (FEES-CONARE), A9-180, A9-902, 805-A9-532 (CSUCAASDI), B3-600, B3-413 (CI), B0-065, B4-227, B5-601, B5-295 and 808-B5-298. Thanks to José L. Vargas and Alberto Salazar for all the logistic support during the expeditions as well as the scientists, rangers and crew participants that collaborated with setting up the meteorological stations. The authors also acknowledge the comments and suggestions by Hugo Hidalgo and the anonymous reviewers which improved the quality of the manuscript.

\section{RESUMEN}

Rodeada por las aguas del Pacífico e historias de naufragios y piratas, una de las islas con mayores lluvias en el Pacífico oriental protege un tesoro de biodiversidad: La Isla del Coco. Este estudio presenta un análisis de las fuentes de humedad relacionadas con las contribuciones a la precipitación en la región. El ciclo diurno de la precipitación en la isla fue revisado utilizando datos de una estación meteorológica del arreglo GPS de COCONet previamente evaluada con datos de estaciones meteorológicas automáticas de campañas de observación realizadas entre 2011 y 2012. Los patrones de salinidad cerca de la superficie fueron analizados junto con temperatura superficial del mar, evaporación, radiación saliente de onda larga así como flujos de calor sensible y calor latente. Las contribuciones de la humedad a la precipitación en la isla es proporcionada por fuentes evaporativas y el reciclaje de humedad es también un proceso relevante. La lluvia regional es un suplidor de humedad continuo mientras que el transporte de humedad tiene un comportamiento estacional muy bien definido. El análisis del ciclo diurno del suministro de humedad sugiere que las contribuciones de humedad relacionadas con el reciclaje de precipitación muestran una respuesta ligeramente desfasada a la convección profunda en la región. El ciclo diurno de las contribuciones de las fuentes evaporativas, basado en los resultados del modelado, es consistente con el ciclo diurno de la precipitación en la isla. El análisis de trayectorias remarca el papel de los vientos de bajo nivel, la posición de la Zona de Convergencia Inter Tropical y las condiciones de estabilidad para modular el suministro de humedad. Las contribuciones de las fuentes evaporativas presentan una sensitividad a El Niño- Oscilación del Sur (ENOS). Las contribuciones del reciclaje de humedad muestran una fuerte variabilidad relacionada con el ENOS como un aumento del aporte de humedad durante eventos cálidos del ENOS durante los meses de verano y otoño boreal. La variabilidad de las contribuciones de la fuente evaporativa Noreste es modulada por la respuesta del Jet de Bajo Nivel del Caribe al ENOS. La fuente evaporativa Suroeste es sensitiva al Niño, el transporte de humedad disminuye (aumenta) entre Noviembre y Marzo (Mayo a Julio) mientras que la respuesta a la Niña se determinó como débil. Se encontró una buena relación entre la respuesta de los campos analizados al ENOS y la dinámica regional.

Palabras clave: Isla del Coco, evaporación, transporte de humedad, precipitación, salinidad, temperatura ENOS, Pacífico Tropical del Este. 


\section{REFERENCES}

Alfaro, E. J. (2008). Ciclo diario y anual de variables troposféricas y oceánicas en la Isla del Coco, Costa Rica. Revista de Biología Tropical, 56(Supplement 2), 19-29.

Alfaro, E. J., \& Hidalgo, H. (2016). Climate of an oceanic island in the Eastern Pacific: Isla del Coco, Costa Rica, Central America. Revista de Biología Tropical, 64(Supplement 1), 59-74.

Amador, J. A. (1998). A climatic feature of the tropical Americas: The trade wind easterly jet. Tópicos Meteorológicos y Oceanográficos, 5(2), 1-13.

Amador, J. A. (2008). The Intra Americas Seas Low-Level Jet (IALLJ): Overview and future research. Annals of the New York Academy of Sciences, 1146, 153-188.

Amador, J., Durán-Quesada, A. M, Rivera, E. R., Mora, G., Sáenz, F., Calderón, B., \& Mora, N. (2016). The easternmost tropical Pacific. Part II: Interannual and intraseasonal variability modes. Revista de Biología Tropical, 64(Supplement 1), S23-S57.

Bain, C. L., Magnusdottir, G., Smyth, P., \& Stern, H. (2010). Diurnal cycle of the Intertropical Convergence Zone in the east Pacific. Journal of Geophysical Research, 115, D23116. doi:10.1029/2010JD014835

Carton, J. A., \& Giese, B. S. (2008). A reanalysis of ocean climate using Simple Ocean Data Assimilation (SODA). Monthly Weather Review, 136(8), 2999-3017.

Chelliah, M., \& Arkin, P. (1992). Large-Scale Interannual variability of monthly Outgoing Longwave Radiation anomalies over the Global Tropics. Journal of Climate, 5, 371-389.

Cook, K. H., \& Vizy, E. K. (2010). Hydrodynamics of the Caribbean low-level jet and its relationship to precipitation. Journal of Climate, 23(6), 1477-1494.

Cortés, J. (2008). Historia de la investigación marina de la Isla del Coco, Costa Rica. Revista de Biología Tropical, 56(Supplement 2), 1-18.

Cortés, J. (2012). Investigaciones marinas en el Parque Nacional Isla de Coco, Costa Rica. Revista de Biología Tropical, 60(Supplement 3), 1-394.

Cortés, J., Morales, A., Lizano, O., Alfaro, E., Moreno, M., Sibaja, J., Gómez, E., Gavlas, A., García, J., Ruiz, E., Nivia, J., Murillo, G., \& Salazar, A. (2011). Informe de la expedición científica UCR-UNA-COCO-IV. San José, Costa Rica: Vicerrectoría de Investigación, Universidad de Costa Rica. Retrieved from http://kerwa. ucr.ac.cr/handle/10669/490

Cortés, J., Morales, A., Lizano, O., Alfaro, E., Acuña, J., Murillo, D., Salazar, J., Ruiz, E., Nivia, J., Salazar, A., Corrales, M., León, L., Márquez, A., Mora, L., \& Vásquez-Brenes, M. (2012). Informe de la expedición cientifica UCR-UNA-COCO-V. San José, Costa
Rica: Vicerrectoría de Investigación, Universidad de Costa Rica. Retrieved from http://kerwa.ucr.ac.cr/ handle/10669/632

Dee, D. P., Uppala, S. M., Simmons, A. J., Berrisford, P., Poli, P., Kobayashi, S., ... \& Vitart, F. (2011). The ERA-Interim reanalysis: Configuration and performance of the data assimilation system. Quarterly Journal of the Royal Meteorological Society, 137(656), 553-597.

Dorling, S. R., Davies, T. D., \& Pierce, C. E. (1992). Cluster analysis: a technique for estimating the synoptic meteorological controls on air and precipitation chemistry-method and applications. Atmospheric Environment. Part A. General Topics, 26(14), 2575-2581.

Durán-Quesada, A. M (2012). Sources of moisture for Central America and transport based on a Lagrangian approach: variability, contributions to precipitation and transport mechanisms. (Unpublished doctoral dissertation). University of Vigo, Vigo, Spain.

Durán-Quesada, A. M., Gimeno, L., Amador, J. A., \& Nieto, R. (2010). Moisture sources for Central America: Identification of moisture sources using a Lagrangian analysis technique. Journal of Geophysical Research: Atmospheres (1984-2012), 115, (D5).

Fernández, W. (1984). Comments on meteorological and climatological observations on Coco Island. Revista Geofisica, 20, 9-19.

Maldonado, T., \& Alfaro, E. (2012). Revisión y comparación de escenarios de cambio climático para el Parque Nacional Isla del Coco, Costa Rica. Revista de Biología Tropical, 60(Supplement 3), 83-112.

Mapes, B. E., Warner, T. T., Xu, M., \& Negri, A. J. (2003). Diurnal patterns of rainfall in northwestern South America. Part I: Observations and context. Monthly Weather Review, 131(5), 799-812.

Montoya, M. (2007). Conozca la Isla del Coco. Una guía para su visitación. BioCursos para amantes de la Naturaleza. Conozca el Parque Nacional isla del Coco. La isla del Tesoro. Organización para Estudios Tropicales (OET), San José, Costa Rica, 29 abril al 6 de mayo 2007.

Pittier, H. F. (1898). Apuntamientos preliminares sobre la Isla del Coco, posesión costarricense en el Océano Pacífico. In Reproducciones Científicas, una Expedición y Legislación de la Isla del Coco, 1963 (pp. 15-28). San José, Costa Rica: Instituto Geográfico de Costa Rica, Ministerio de Transportes.

Poveda, G., \& Mesa, O. J. (2000). On the existence of Lloró (the rainiest locality on Earth): Enhanced ocean-land-atmosphere interaction by a low-level jet. Geophysical Research Letters, 27(11), 1675-1678.

Poveda, G., Waylen, P. R., \& Pulwarty, R. S. (2006). Annual and inter-annual variability of the present 
climate in northern South America and southern Mesoamerica. Palaeogeography, Palaeoclimatology, Palaeoecology, 234(1), 3-27.

Protti, E. (1964). Ensayo sobre el clima de la Isla del Coco. Nuevos apuntes y bibliografía de la Isla del Coco. Serie geográfica, 2, 27-28.

Protti, M., González, V., Freymueller, J., \& Doelger, S. (2012). Isla del Coco, on Cocos Plate, converges with Isla de San Andrés, on the Caribbean Plate, at $78 \mathrm{~mm} /$ yr. Revista de Biología Tropical, 60(Supplement 3), 33-41.

Quirós-Badilla, E., \& Alfaro, E. J. (2009). Algunos aspectos relacionados con la variabilidad climática en la Isla del Coco, Costa Rica. Revista de Climatología, 9, 33-34.

Reynolds, R. W., Smith, T. M., Liu, C., Chelton, D. B., Casey, K. S., \& Schlax, M. G. (2007). Daily highresolution-blended analyses for sea surface temperature. Journal of Climate, 20, 5473-5496.
Stohl, A., \& James, P. (2004). A Lagrangian analysis of the atmospheric branch of the global water cycle. Part I: Method description, validation, and demonstration for the August 2002 flooding in central Europe. Journal of Hydrometeorology, 5(4), 656-678.

Stohl, A., Forster, C., Frank, A., Seibert, P., \& Wotawa, G. (2005). Technical note: The Lagrangian particle dispersion model FLEXPART version 6.2. Atmospheric Chemistry and Physics, 5(9), 2461-2474.

Xie, S. P., Xu, H., Kessler, W. S., \& Nonaka, M. (2005). Air-Sea Interaction over the Eastern Pacific Warm Pool: Gap Winds, Thermocline Dome, and Atmospheric Convection. Journal of. Climate, 18, 5-20.

Yu, L., Jin, X., \& Weller, R. A. (2008). Multidecade Global Flux Datasets from the Objectively Analyzed Air-sea Fluxes (OAFlux) Project: Latent and Sensible Heat Fluxes, Ocean Evaporation, and Related Surface Meteorological Variables Lisan Yu. (OAFlux Project Tech. Rep. OA-2008-01). Massachusetts, USA: Woods Hole Oceanographic Institution. 
